\title{
Adaptation and Validation of The Children's Worlds Subjective Well-Being Scale (CW-SWBS) in Indonesia
}

\author{
Ihsana Sabriani Borualogo', E Ferran Casas ${ }^{2}$ \\ ${ }^{1}$ Universitas Islam Bandung \\ ${ }^{2}$ Research Institute on Quality of Life, Universitat de Girona
}

\begin{abstract}
The Indonesian research team participating in the Children's Worlds international project has used a new context-free multi-item scale named CW-SWBS (Children's Worlds Subjective Well-Being Scale). This psychometric instrument was previously never used in Indonesia. This study aimed to validate the adapted Indonesia language version for a representative sample of children who are elementary students in West Java province $(\mathrm{N}=22,616)$, ranging from 8,10 , to 12-year-olds. Confirmatory Factor Analysis (CFA) was used to test the fit of the psychometric scale, and multi-group CFA was used to check the comparability between answers given by gender and school types. Result findings showed that the instrument displays excellent fit for measuring life satisfaction in Indonesian children using five items, instead of the six original items. Answers to the items of the CW-SWBS by gender and school types were demonstrated to be comparable, suggesting that there was no different answering style between individuals in these studied groups.
\end{abstract}

Keywords: children; confirmatory factor analysis; Indonesia; life satisfaction; subjective well-being

SWB is defined as a person's evaluations of their lives - the degree to which their thoughtful appraisals and affective reactions indicate that their lives are desirable and proceeding well (Diener, 1984; Diener \& Lucas, 2015). There are several instruments to measure adults' subjective well-being, e.g., SWLS (Diener, Emmons, \& Griffin, 1985) and SLSS (Huebner, 1991). Study on SWB expands not only on adults but also on children's SWB. Children's subjective well-being (SWB) has a dual meaning: (a) it refers to subjective data, collected using subjective measuring techniques; and (b) it usually refers to the hedonic tradition in research on well-being (Casas, 2016b).

In the hedonic tradition, SWB is usually defined as having three components: positive affect, negative affect, and life satisfaction (Casas, 2016b). There is a consensus that life satisfaction can be measured using two different procedures: (a) by assessing context-free overall life satisfaction - using either a single-item or a multi-item psychometric scale; and (b) by evaluating satisfaction with the most relevant life-domains (Casas, 2016b). This article is devoted to a new context-free multi-item scale used for Indonesian children and adolescents.

\footnotetext{
${ }^{1}$ Address for corespondence:

ihsana.sabriani@yahoo.com
} 
Although the study of SWB has mainly focused on adults during decades, increasing interest in children's SWB has been observed during recent years in the scientific literature. Recently, numerous studies have investigated SWB among children in different countries (Casas, 2016a; Casas, Bello, González, \& Aligué, 2012; Land, Lamb, \& Mustillo, 2014; Savahl, Casas, \& Adams, 2017). Efforts to measure children's subjective well-being have expanded in recent years. The government has done various collaboration projects with non-governmental organizations and academic institutions.

One of them is the Children's Worlds project, which conducts an international interdisciplinary survey of children's SWB (www.isciweb.org). Children's Worlds has proposed a new data collection in as many countries as possible using a questionnaire which explores children's activities, perceptions, and satisfaction about their everyday life. A range of life domains and children's opinions on different topics affecting them is considered using three psychometric scales (Rees, Andresen \& Bradshaw, 2016). The questionnaires of this project include the items of the psychometric scale we have analyzed here.

Currently, the Children's Worlds project is developing its third wave of data collection in about 40 countries. Indonesia participated in this international survey in a collaboration work between UNISBA (Universitas Islam Bandung) and UNICEF Indonesia. This project in Indonesia is significant since Indonesia is among the countries that have taken the lead in the development of the new Sustainable Development Goals (SDGs). An essential aspect of the SDGs is their universality and equity focus - no goal will be considered achieved if it has not been completed for all groups of the population, including children and all geographic areas of a country. This call for a new approach is conducted to monitor disparities in children's well-being that goes beyond routine administrative and household survey data that takes into account the voices of children themselves.

Indonesia is highly decentralized with 33 provinces and more than 500 districts. Java is the most populated island, and West Java is one of the most populated provinces after Jakarta. West Java has about eight million children aged 5-14 years. The aim of the pilot data collection in West Java was to develop the children's survey as a tool to monitor child well-being in West Java. The results of this survey could bring a new perspective on how government and stakeholders think about children and plan programs and interventions.

After carefully searching in scientific journals, we had not been able to identify any previous adaptation and validation of this instrument or any similar one into the Indonesian language. Therefore, this study will be valuable for other researchers who may benefit from using CW-SWBS on their data collection with children or adolescents in Indonesia.

The aim of this study was to validate a new context-free multi-item scale named CW-SWBS (Children's Worlds Subjective Well-Being Scale) for three different age groups in late childhood and early adolescence $(8,10$, and 12 year olds) in Indonesia, and to check for its comparability among gender and types of school (measurement invariance).

\section{Methods}

Sample

Participants were elementary school students from 27 districts in West Java Province, Indonesia $(\mathrm{N}=22,616)$. They were in grade $2(32.86 \%, n=7,432)$, grade 4 
$(32.17 \%, \mathrm{n}=7,276)$, and grade $6(34.97 \%, \mathrm{n}=$ $7,908)$. There are $49.48 \%$ boys $(n=11,191)$, and $49.75 \%$ girls $(n=11,251)$, and $0.77 \%$ children $(n=174)$ did not answer the question about gender.

Age and gender distribution, according to grade, is displayed in Table 1. Data presented in Table 1 were data from each age group database still including children missing values, which is why the size of the sample $(\mathrm{N}=22,652)$ was different with the size of the depurated database $(\mathrm{N}=22,616)$.

\section{Procedure}

A stratified cluster random sampling was used to select representative samples of children. Based on the calculation for $\mathrm{p}=.7$ for each district, a $90 \%$ confidence level, a margin of error is about $5 \%$, a $90 \%$ response rate, and design effect (DEFF) 1.5, the number of students to be sampled in each school was decided to be about 400 children. Within each district, ten schools were selected, including public and private schools, across religious-based and nonreligious-based schools.

Before we started data collection, we requested the ethical committee in Universitas Padjadjaran to approve our research project with children. After that, we asked for permission to the Ministry of Education and the Ministry of Religion at the provincial level of West Java. After we received the approval letters, we went to the schools and requested to the principal of the selected schools for data taking. There were ten selected schools in 27 districts in West Java Province. There were 267 schools that the principals of the schools agreed to participate, and next, we sent the consent to parents through teachers. When parents obtained written consent, we also asked the children for their cooperation. We informed the children that the data would be treated confidentially and that they were free to answer or not to any question.

Table 1.

Sample Distribution by Grade, Age, and Gender

\begin{tabular}{|c|c|c|c|c|c|c|c|c|c|c|c|c|}
\hline \multirow[t]{2}{*}{ Age } & \multicolumn{3}{|c|}{$\begin{array}{c}\text { Grade } 2 \\
\text { (8-year-old age group) }\end{array}$} & \multicolumn{3}{|c|}{$\begin{array}{c}\text { Grade } 4 \\
\text { (10-year-old age } \\
\text { group) }\end{array}$} & \multicolumn{3}{|c|}{$\begin{array}{c}\text { Grade } 6 \\
\text { (12-year-old age } \\
\text { group) }\end{array}$} & \multicolumn{3}{|c|}{ TOTAL } \\
\hline & Boys & Girls & Total & Boys & Girls & Total & Boys & Girls & Total & Boys & Girls & Total \\
\hline 6 & 113 & 103 & 216 & & & & & & & 113 & 103 & 216 \\
\hline 7 & 1,372 & 1,719 & 3,091 & & & & & & & 1,372 & 1,719 & 3,091 \\
\hline 8 & 1,960 & 1,702 & 3,662 & 80 & 95 & 175 & & & & 2,040 & 1,797 & 3,837 \\
\hline 9 & 230 & 111 & 341 & 1,504 & 1,917 & 3,421 & & & & 1,734 & 2,028 & 3,762 \\
\hline 10 & 29 & 18 & 47 & 1,828 & 1,514 & 3,342 & 83 & 154 & 237 & 1,940 & 1,686 & 3,626 \\
\hline 11 & 1 & 0 & 1 & 269 & 127 & 396 & 1,760 & 2,291 & 4,051 & 2,030 & 2,418 & 4,448 \\
\hline 12 & & & & 46 & 18 & 64 & 1,761 & 1,449 & 3,210 & 1,807 & 1,467 & 3,274 \\
\hline 13 & & & & & & & 235 & 119 & 354 & 235 & 119 & 354 \\
\hline 14 & & & & & & & 30 & 14 & 44 & 30 & 14 & 44 \\
\hline TOTAL & 3,705 & 3,653 & 7,358 & 3,727 & 3,671 & 7,398 & 3,869 & 4,027 & 7,896 & 11,301 & 11,351 & 22,652 \\
\hline
\end{tabular}


Data were collected in regular classrooms and self-administered. One of their usual teachers and two skilled enumerators were present in the classroom during the administration of the questionnaire to answer any questions which might arise. Teachers did not do the data collection, and they presented in the classroom only for maintaining the conducive situation in the classroom. Before the data collection started, children responded to questions on a training sheet.

\section{Instrument:}

\section{CW-SWBS}

In the Children's Worlds project first wave survey, the questionnaires for both 10 and 12-year-olds included the original items of the Student's Life Satisfaction Scale (SLSS), developed in the US by (Huebner, 1991). Because of the well-known optimistic bias effect, particularly crucial among children, unlike the original version an 11-point scale from 'Do not agree at all' to 'Totally agree' was used, to make the instrument more sensitive and capture more variance. This option had already been adopted by some authors with similar scales when administered to adolescents (e.g., with Diener, 1984; Diener et al., 1985; in Casas et al., 2012).

For the second wave, the research team adopted additional modifications of the scale, i.e., not including any of the reversed items, and added one more item ('the things in my life are excellent') adapted from the SWLS, in order to improve the scale's reliability (Rees et al., 2016).

Careful analysis of the second wave results suggested that some of the items were not working well enough, particularly for children that answered the questionnaire in non-Indo-European languages, like Nepal (Casas, 2016a). For that reason, in the third wave, several of its original items were substituted by other items to be tested in as many countries as possible. Children from different non-IndoEuropean speaking languages were asked to advise researchers how to improve the scale and the wording for the items, and as a consequence, added new items, and deleted one item. The final version of this scale is slightly different from the original Huebner's scale, and for that reason, although recognizing the origins, the Children's Worlds project decided to rename this modified version as CW-SWBS (Children's Worlds Subjective Well-Being Scale) (www.isciweb.org). Because we finally used a new psychometric scale, we had to test validity and reliability for Indonesian children - and we conducted the test using Confirmatory Factor Analysis (CFA) by each age group.

The version for the 8-year-old group used the same wording for each item but with a different scale, because instead of using a 0-10 scale, we used five emoticons. These emoticons were advised by children when the first wave questionnaire was designed (Casas, González, Navarro, \& Aligue, 2013).

Additionally, we would check for comparability between gender and types of school by using multi-group CFA to be sure that this scale is properly functioning when used with different groups of Indonesian children. Therefore, we can report that there is a consistent answering style in the Indonesian language.

Since the original version of the questionnaire was in English, we translated it into Bahasa Indonesia, which is the language all school children understand in Indonesia. Then we back-translated into English to assure and validate the translated version (Borualogo et al., 2018) (see Table 2). 
Table 2.

English Version and Indonesian Version of the CW-SWB Psychometric Scale

\begin{tabular}{|c|c|c|}
\hline English Original Version & Indonesian Translation & English Back Translation \\
\hline $\begin{array}{l}\text { Now please say how much you } \\
\text { agree with each of the } \\
\text { following sentences about your } \\
\text { life as a whole. }\end{array}$ & $\begin{array}{l}\text { Sekarang tolong jelaskan seberapa } \\
\text { setuju kamu dengan kalimat- } \\
\text { kalimat dibawah ini mengenai } \\
\text { kehidupanmu secara umum. }\end{array}$ & $\begin{array}{l}\text { Now please explain how much } \\
\text { do you agree with the } \\
\text { following sentences about your } \\
\text { life in general. }\end{array}$ \\
\hline $\begin{array}{l}\text { These questions use a scale } \\
\text { from } 0 \text { to } 10 \text { where } 0 \text { means } \\
\text { that you do not agree with the } \\
\text { sentence at all, and } 10 \text { means } \\
\text { that you agree with it } \\
\text { completely. }\end{array}$ & $\begin{array}{l}\text { Pernyataan-pernyataan ini } \\
\text { menggunakan angka dari } 0 \\
\text { sampai 10, dimana angka } 0 \\
\text { berarti bahwa kamu "sama sekali } \\
\text { tidak setuju" dengan pernyataan } \\
\text { tersebut, dan } 10 \text { berarti bahwa } \\
\text { kamu "benar-benar setuju" } \\
\text { dengan pernyataan tersebut. }\end{array}$ & $\begin{array}{l}\text { The following sentences using } \\
\text { scale } 0 \text { to } 10 \text {, when } 0 \text { means } \\
\text { you strongly do not agree with } \\
\text { the statement, and } 10 \text { means } \\
\text { that you strongly agree with } \\
\text { the statement. }\end{array}$ \\
\hline I enjoy my life & Saya menikmati hidup saya & I enjoy my life \\
\hline My life is going well & $\begin{array}{l}\text { Kehidupan saya berjalan dengan } \\
\text { baik }\end{array}$ & My life is going well \\
\hline I have a good life & $\begin{array}{l}\text { Saya memiliki kehidupan yang } \\
\text { baik }\end{array}$ & My life is fine \\
\hline $\begin{array}{l}\text { The things that happen in my } \\
\text { life are excellent }\end{array}$ & $\begin{array}{l}\text { Hal-hal yang terjadi dalam } \\
\text { kehidupan saya sangat baik }\end{array}$ & $\begin{array}{l}\text { Things happening in my life } \\
\text { are very good }\end{array}$ \\
\hline I like my life & Saya menyukai kehidupan saya & I like my life \\
\hline I am happy with my life & $\begin{array}{l}\text { Saya senang/bahagia dengan } \\
\text { kehidupan saya }\end{array}$ & I am happy with my life \\
\hline
\end{tabular}

\section{Demographic variables}

We collected data about gender, and about the types of school: (a) public or private; (b) general (non-religious) or religious. The 8year-old group sample included 3,705 boys $(50.4 \%)$ and 3,653 girls. There were 6,257 children attending private schools $(85.1 \%)$ and 1,101 attending public schools. There were 5,801 attending general (nonreligious) schools (78.8\%) and 1,557 attending religious schools.

The 10-year-old group sample included 3,727 boys (50.3\%) and 3,671 girls. There were 6,285 children attending private schools (84.9\%) and 1,113 attending public schools. There were 5,877 attending general (non-religious) schools (79.5\%) and 1,519 attending religious schools. The 12-yearold group sample includes 3,869 boys (48.9\%) and 4,027 girls. There were 6,538 children attending private schools $(82.8 \%)$ and 1,358 attending public schools. There were 6,333 attending general (nonreligious) schools (80.2\%) and 1,563 attending religious schools.

\section{Statistical analysis}

To develop CFA with the Indonesian data, we organized each of the three age-group databases appropriately. We deleted all individuals displaying 3 or more missing values for the items of CW-SWBS. As a consequence, we removed 164 subjects from the original database (12 for the 12- 
year-old age group, 78 for the 10-year-old age group, and 74 for the 8 -year-old age group). The remaining missing values were substituted by multiple imputations using regression as implemented by the SPSS23.

To first assess the validity of the factorial structure of the multi-item scale, we tested different CFA models using AMOS23, with maximum likelihood estimation. Because subjective well-being data usually differ significantly from multivariate normality, data were handled utilizing the bootstrap method to compute standard errors.

The fit indices considered were the CFI (Comparative Fix Index), RMSEA (Root Mean Square Error of Approximation) and SRMR (Standardized Root Mean Square Residual). We assumed that results higher than .950 for the CFI and results below .05 for the RMSEA and SRMR are excellent, following Arbuckle (2010) and Byrne (2010).

To meaningfully compare statistics across groups, required measurement invariance. Three steps necessary to be conducted include (a) configural invariance (unconstrained variables); (b) metric invariance (constrained factor loadings); and (c) scalar invariance (constrained factor loadings and intercepts). Metric invariance allows meaningful comparison of correlation and regressions. On the other hand, scalar invariance allows meaningful comparison of the latent means (Coenders, Batista-Foguer \& Saris, 2005). Therefore, we tested each multi-group model in three steps. When any constraint is added to a model, a change in the CFI of more than .01 is considered unacceptable (Chen, 2007).

\section{Results}

\section{Descriptive statistics}

Table 3 presented descriptive statistics for each item by age. The mean scores for the 6 items in the 8-year-old group were slightly lower than for 10-year-old and 12-year-old groups. The item "the things that happen in my life are excellent" displayed the lowest means among other items in the three age groups.

\section{Confirmatory factor analysis}

The initial model had been designed relating the 6 items of the CW-SWBS to a latent variable, and the model had been tested separately for each age group.

Table 3.

Descriptive Statistics for CW-SWBS

\begin{tabular}{lcccccc}
\hline & \multicolumn{2}{c}{$\begin{array}{c}\text { 8 Year Olds } \\
\text { (Grade 2) }\end{array}$} & \multicolumn{2}{c}{$\begin{array}{c}\text { 10 Year Olds } \\
\text { (Grade 4) }\end{array}$} & \multicolumn{2}{c}{$\begin{array}{c}\text { 12 Year Olds } \\
\text { (Grade 6) }\end{array}$} \\
\cline { 2 - 7 } & Mean & Std. dev & Mean & Std. dev & Mean & Std. dev \\
\hline I enjoy my life & 8.21 & 2.97 & 8.66 & 2.23 & 8.72 & 1.84 \\
My life is going well & 8.42 & 2.58 & 8.73 & 2.13 & 8.68 & 1.84 \\
I have a good life & 8.35 & 2.56 & 8.78 & 2.10 & 8.76 & 1.77 \\
The things that happen in my life & 8.03 & 2.88 & 8.38 & 2.38 & 8.25 & 2.06 \\
are excellent & & & & & & \\
I like my life & 8.14 & 2.97 & 8.73 & 2.16 & 8.72 & 1.85 \\
I am happy with my life & 8.26 & 2.83 & 8.80 & 2.11 & 8.84 & 1.75 \\
\hline
\end{tabular}




\section{BORUALOGO \& CASAS}

12 year old group

Table 4 showed that the initial model displays only a highly moderate fit for the RMSEA. When the item "I like my life" was not included in the model, fit statistics became excellent (Model 2 in Table 4, and Figure 1).
10 year old group

In Table 5, we observed that the initial model displays only a moderate fit for the RMSEA. Like with the 12-year-olds groups, when the item "I like my life" was not included in the model, fits statistics became excellent (Model 2 in Table 5, and Figure 2).

Table 4.

CFA Fit Statistics for the Factor Structure for 12-Year-Old Group

\begin{tabular}{|c|c|c|c|c|c|c|c|c|}
\hline No & Model & & $\chi^{2}$ & df & $p$-value & CFI & $\begin{array}{l}\text { RMSEA } \\
\text { (confidence } \\
\text { interval) } \\
\end{array}$ & SRMR \\
\hline 1 & $\begin{array}{l}\text { Initial model CW- } \\
\text { SWBS }\end{array}$ & Pooled sample & 448.17 & 9 & .000 & .983 & $\begin{array}{c}.078 \\
(.072-.085)\end{array}$ & .020 \\
\hline 2 & $\begin{array}{l}\text { CW-SWBS with } 5 \\
\text { items }\end{array}$ & Pooled sample & 93.79 & 5 & .000 & .995 & $\begin{array}{c}.047 \\
(.039-.056)\end{array}$ & .012 \\
\hline 3 & $\begin{array}{l}\text { CW-SWBS5 } \\
\text { Multi-group Gender }\end{array}$ & Unconstrained & 121.49 & 10 & .000 & .994 & $\begin{array}{c}.038 \\
(.032-.044)\end{array}$ & .014 \\
\hline 4 & $\begin{array}{l}\text { CW-SWBS5 } \\
\text { Multi-group Gender }\end{array}$ & $\begin{array}{l}\text { Constrained } \\
\text { loadings }\end{array}$ & 124.16 & 14 & .000 & .994 & $\begin{array}{c}.032 \\
(.027-.037)\end{array}$ & .014 \\
\hline 5 & $\begin{array}{l}\text { CW-SWBS5 Multi- } \\
\text { group Gender }\end{array}$ & $\begin{array}{l}\text { Constrained } \\
\text { loadings \& } \\
\text { intercepts }\end{array}$ & 149.37 & 18 & .000 & .993 & $\begin{array}{c}.030 \\
(.026-.035)\end{array}$ & .014 \\
\hline 6 & $\begin{array}{l}\text { CW-SWBS5 Multi- } \\
\text { group Public/private } \\
\text { school }\end{array}$ & Unconstrained & 104.46 & 10 & .000 & .995 & $\begin{array}{c}.034 \\
(.029-.041)\end{array}$ & .012 \\
\hline 7 & $\begin{array}{l}\text { CW-SWBS5 Multi- } \\
\text { group Public/private } \\
\text { school }\end{array}$ & $\begin{array}{l}\text { Constrained } \\
\text { loadings }\end{array}$ & 113.80 & 14 & .000 & .995 & $\begin{array}{c}.030 \\
(.025-.035)\end{array}$ & .012 \\
\hline 8 & $\begin{array}{l}\text { CW-SWBS5 Multi- } \\
\text { group Public/private } \\
\text { school }\end{array}$ & $\begin{array}{l}\text { Constrained } \\
\text { loadings \& } \\
\text { intercepts }\end{array}$ & 115.65 & 18 & .000 & .995 & $\begin{array}{c}.026 \\
(.022-.031)\end{array}$ & .012 \\
\hline 9 & $\begin{array}{l}\text { CW-SWBS5 Multi- } \\
\text { group religious/non- } \\
\text { religious school }\end{array}$ & Unconstrained & 105.18 & 10 & .000 & .995 & $\begin{array}{c}.035 \\
(.029-.041)\end{array}$ & .017 \\
\hline 10 & $\begin{array}{l}\text { CW-SWBS5 Multi- } \\
\text { group religious/non- } \\
\text { religious school }\end{array}$ & $\begin{array}{l}\text { Constrained } \\
\text { loadings }\end{array}$ & 107.12 & 14 & .000 & .995 & $\begin{array}{c}.029 \\
(.024-.034)\end{array}$ & .017 \\
\hline 11 & $\begin{array}{l}\text { CW-SWBS5 Multi- } \\
\text { group religious/non- } \\
\text { religious school }\end{array}$ & $\begin{array}{l}\text { Constrained } \\
\text { loadings \& } \\
\text { intercepts }\end{array}$ & 117.26 & 18 & .000 & .995 & $\begin{array}{c}.026 \\
(.022-.031)\end{array}$ & .017 \\
\hline
\end{tabular}




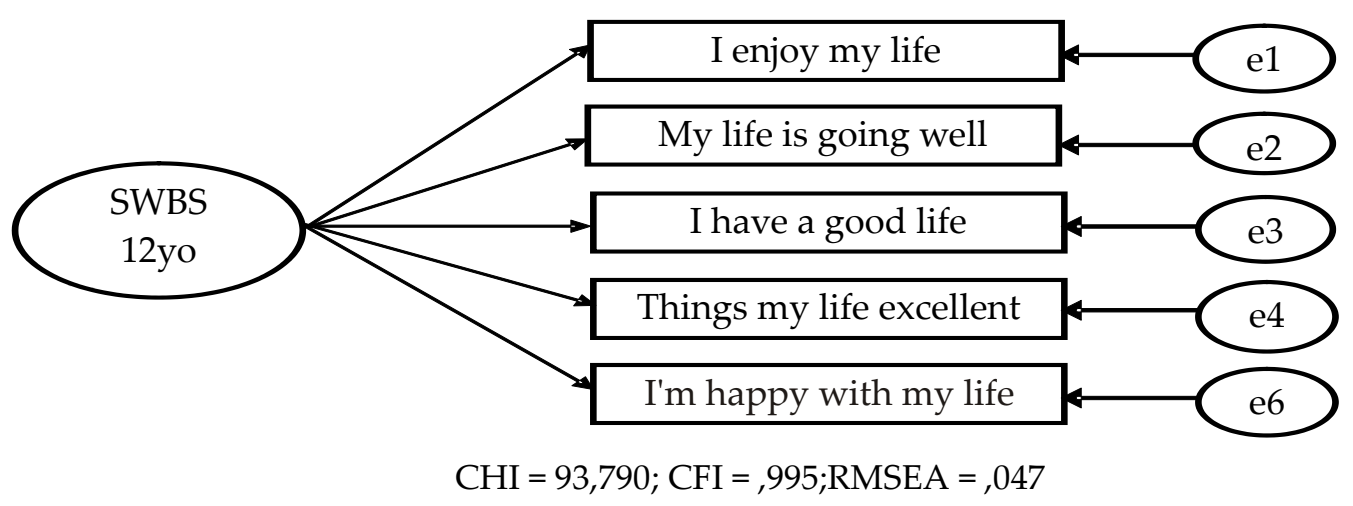

Figure 1. CFA of the context-free multi-item CW-SWBS for 12 year-olds

Table 5.

CFA Fit Statistics for the Factor Structure for 10 Year Old Group

\begin{tabular}{|c|c|c|c|c|c|c|c|c|}
\hline No & Model & & $\chi^{2}$ & df & $p$-value & CFI & $\begin{array}{c}\text { RMSEA } \\
\text { (confidence } \\
\text { interval) }\end{array}$ & SRMR \\
\hline 1 & Initial model CW-SWBS & Pooled sample & 393.45 & 9 & .000 & .980 & $\begin{array}{c}.076 \\
(.069-.082)\end{array}$ & .023 \\
\hline 2 & CW-SWBS with 5 items & Pooled sample & 75.17 & 5 & .000 & .995 & $\begin{array}{c}.043 \\
(.035-.052)\end{array}$ & .013 \\
\hline 3 & $\begin{array}{l}\text { CW-SWBS5 } \\
\text { Multi-group Gender }\end{array}$ & Unconstrained & 99.11 & 10 & .000 & .994 & $\begin{array}{c}.035 \\
(.029-.041)\end{array}$ & .018 \\
\hline 4 & $\begin{array}{l}\text { CW-SWBS5 } \\
\text { Multi-group Gender }\end{array}$ & $\begin{array}{l}\text { Constrained } \\
\text { loadings }\end{array}$ & 109.51 & 14 & .000 & .993 & $\begin{array}{c}.030 \\
(.025-.036)\end{array}$ & .019 \\
\hline 5 & $\begin{array}{l}\text { CW-SWBS5 Multi- } \\
\text { group Gender }\end{array}$ & $\begin{array}{l}\text { Constrained } \\
\text { loadings \& } \\
\text { intercepts }\end{array}$ & 119.75 & 18 & .000 & .993 & $\begin{array}{c}.028 \\
(.023-.032)\end{array}$ & .019 \\
\hline 6 & $\begin{array}{l}\text { CW-SWBS5 Multi- } \\
\text { group Public/private } \\
\text { school }\end{array}$ & Unconstrained & 101.00 & 10 & .000 & .993 & $\begin{array}{c}.035 \\
(.029-.041)\end{array}$ & .014 \\
\hline 7 & $\begin{array}{l}\text { CW-SWBS5 Multi- } \\
\text { group Public/private } \\
\text { school }\end{array}$ & $\begin{array}{l}\text { Constrained } \\
\text { loadings }\end{array}$ & 126.34 & 14 & .000 & .992 & $\begin{array}{c}.033 \\
(.028-.031)\end{array}$ & .015 \\
\hline 8 & $\begin{array}{l}\text { CW-SWBS5 Multi- } \\
\text { group Public/private } \\
\text { school }\end{array}$ & $\begin{array}{l}\text { Constrained } \\
\text { loadings \& } \\
\text { intercepts }\end{array}$ & 141.44 & 18 & .000 & .991 & $\begin{array}{c}.030 \\
(.026-.035)\end{array}$ & .015 \\
\hline 9 & $\begin{array}{l}\text { CW-SWBS5 Multi- } \\
\text { group religious/non- } \\
\text { religious school }\end{array}$ & Unconstrained & 89.11 & 10 & .000 & .994 & $\begin{array}{c}.033 \\
(.027-.039)\end{array}$ & .013 \\
\hline 10 & $\begin{array}{l}\text { CW-SWBS5 Multi- } \\
\text { group religious/non- } \\
\text { religious school }\end{array}$ & $\begin{array}{l}\text { Constrained } \\
\text { loadings }\end{array}$ & 92.38 & 14 & .000 & .994 & $\begin{array}{c}.027 \\
(.022-.033)\end{array}$ & .014 \\
\hline 11 & $\begin{array}{l}\text { CW-SWBS5 Multi- } \\
\text { group religious/non- } \\
\text { religious school }\end{array}$ & $\begin{array}{l}\text { Constrained } \\
\text { loadings \& } \\
\text { intercepts }\end{array}$ & 104.11 & 18 & .000 & .994 & $\begin{array}{c}.025 \\
(.021-.030)\end{array}$ & .014 \\
\hline
\end{tabular}




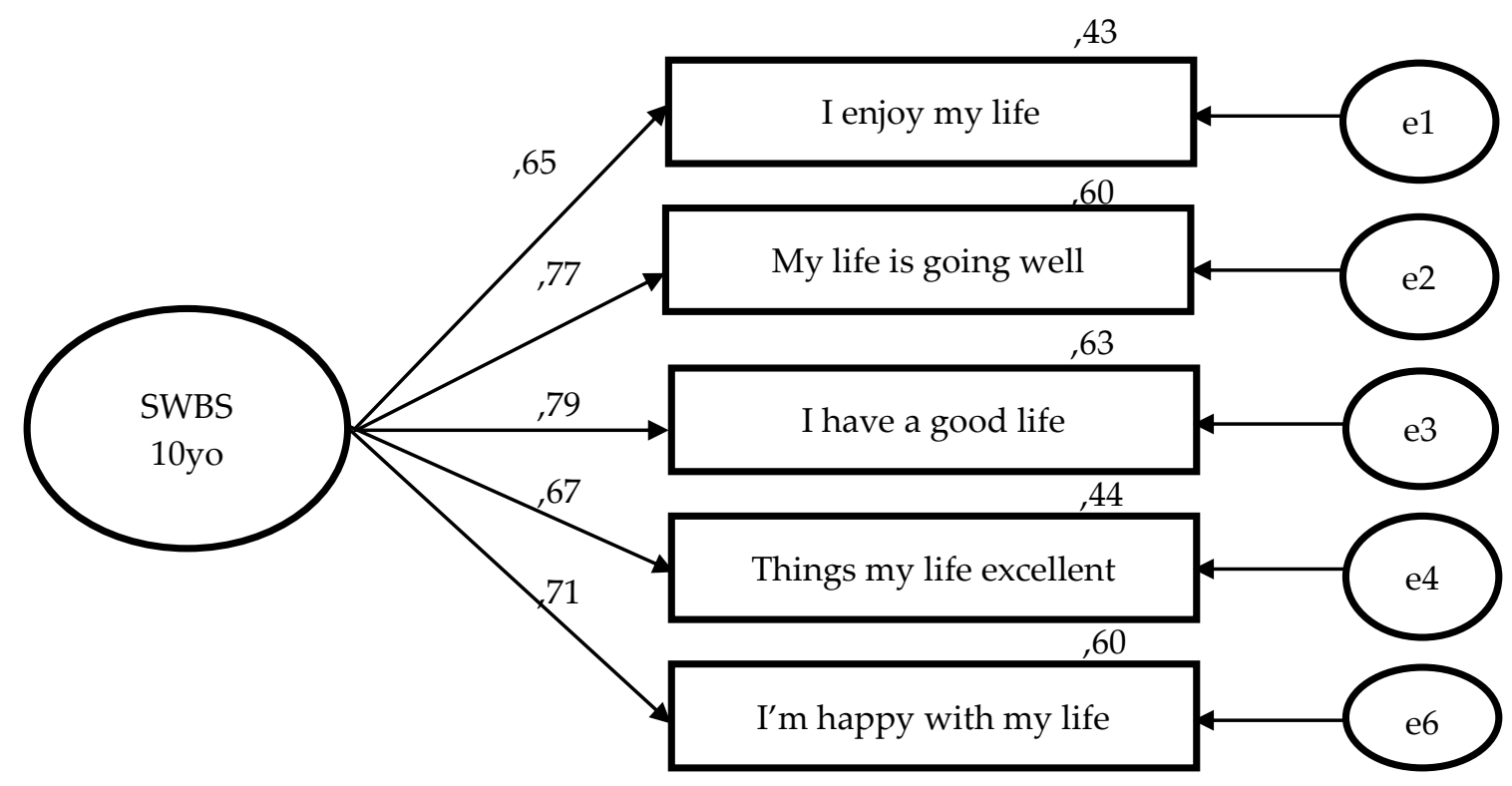

$\mathrm{CHI}=75,165 ; \mathrm{CFI}=0,995 ; \mathrm{RMSEA}=0,043$

Figure 2. CFA of the context-free multi-item CW-SWBS for 10 year-olds

8 year old group

In Table 6, we observed that the initial Model displays only a moderate fit for the RMSEA. Once again, when the item "I like my life" was not included in the model, fits statistics were excellent (Model 2 in Table 6, and Figure 3).

\section{All age groups}

Therefore, we had adopted the 5-item version of the CW-SWBS for all age groups. The next step was to analyze the comparability of the answers of three different dichotomic groups of children (by gender, by public or private school and by religious or non-religious school) using Multi-Group CFA (MCFA) for each age group to check the possible different answering styles between groups. Tables 46 , models 3 to 11 in each table. We could observe that all fit statistics differences when adding one additional constraint were lower than .01 (Chen, 2007; Cheung \&
Rensvold, 2001), meaning that correlation, regressions and mean scores were comparable among all groups for all age groups, and the hypothesis that there are no different answering styles between groups was supported.

Next, we had added the variables age to each age multi-group gender model, for national or private school and religious or non-religious school. As an example, see the fourth path-diagram in Figure 4 for 12year-old boys. Table 7 displayed standardized regression weights with bootstrapping for each grade and gender.

In table 7 , we could observe that the effects of the three variables on the CWSWBS5 were significant for the Grade 2 group for both boys and girls. However, similar to both genders, none of them were substantial for the Grade 6 group, and the only age group that showed weakly significant effects is Grade 4. 
Table 6.

CFA Fit Statistics for the Factor Structure for 8-Year-Old Group

\begin{tabular}{|c|c|c|c|c|c|c|c|c|}
\hline No & Model & & $\chi^{2}$ & df & $p$-value & CFI & $\begin{array}{c}\text { RMSEA } \\
\text { (confidence } \\
\text { interval) } \\
\end{array}$ & SRMR \\
\hline 1 & $\begin{array}{l}\text { Initial model CW- } \\
\text { SWBS }\end{array}$ & Pooled sample & 189.68 & 9 & .000 & .982 & $\begin{array}{c}.052 \\
(.046-.059)\end{array}$ & .022 \\
\hline 2 & CW-SWBS with 5 items & Pooled sample & 94.58 & 5 & .000 & .988 & $\begin{array}{c}.049 \\
(.041-.058)\end{array}$ & .018 \\
\hline 3 & $\begin{array}{l}\text { CW-SWBS5 } \\
\text { Multi-group Gender }\end{array}$ & Unconstrained & 111.79 & 10 & .000 & .986 & $\begin{array}{c}.037 \\
(.031-.044)\end{array}$ & .017 \\
\hline 4 & $\begin{array}{l}\text { CW-SWBS5 } \\
\text { Multi-group Gender }\end{array}$ & $\begin{array}{l}\text { Constrained } \\
\text { loadings }\end{array}$ & 117.41 & 14 & .000 & .986 & $\begin{array}{c}.032 \\
(.027-.037)\end{array}$ & .018 \\
\hline 5 & $\begin{array}{l}\text { CW-SWBS5 } \\
\text { group Gender }\end{array}$ & $\begin{array}{l}\text { Constrained } \\
\text { loadings \& } \\
\text { intercepts }\end{array}$ & 119.79 & 18 & .000 & .986 & $\begin{array}{c}.028 \\
(.023-.033)\end{array}$ & .018 \\
\hline 6 & $\begin{array}{l}\text { CW-SWBS5 Multi- } \\
\text { group Public/private } \\
\text { school }\end{array}$ & Unconstrained & 98.59 & 10 & .000 & .988 & $\begin{array}{c}.035 \\
(.029-.041)\end{array}$ & .018 \\
\hline 7 & $\begin{array}{l}\text { CW-SWBS5 Multi- } \\
\text { group Public/private } \\
\text { school }\end{array}$ & $\begin{array}{l}\text { Constrained } \\
\text { loadings }\end{array}$ & 101.39 & 14 & .000 & .988 & $\begin{array}{c}.029 \\
(.024-.034)\end{array}$ & .018 \\
\hline 8 & $\begin{array}{l}\text { CW-SWBS5 Multi- } \\
\text { group Public/private } \\
\text { school }\end{array}$ & $\begin{array}{l}\text { Constrained } \\
\text { loadings \& } \\
\text { intercepts }\end{array}$ & 120.55 & 18 & .000 & .986 & $\begin{array}{c}.028 \\
(.023-.032)\end{array}$ & .018 \\
\hline 9 & $\begin{array}{l}\text { CW-SWBS5 Multi- } \\
\text { group religious/non- } \\
\text { religious school }\end{array}$ & Unconstrained & 103.51 & 10 & .000 & .987 & $\begin{array}{c}.035 \\
(.029-.042)\end{array}$ & .016 \\
\hline 10 & $\begin{array}{l}\text { CW-SWBS5 Multi- } \\
\text { group religious/non- } \\
\text { religious school }\end{array}$ & $\begin{array}{l}\text { Constrained } \\
\text { loadings }\end{array}$ & 139.07 & 14 & .000 & .986 & $\begin{array}{c}.031 \\
(.026-.036)\end{array}$ & .017 \\
\hline 11 & $\begin{array}{l}\text { CW-SWBS5 Multi- } \\
\text { group religious/non- } \\
\text { religious school }\end{array}$ & $\begin{array}{l}\text { Constrained } \\
\text { loadings \& } \\
\text { intercepts }\end{array}$ & 127.83 & 18 & .000 & .985 & $\begin{array}{c}.029 \\
(.024-.033)\end{array}$ & .016 \\
\hline
\end{tabular}

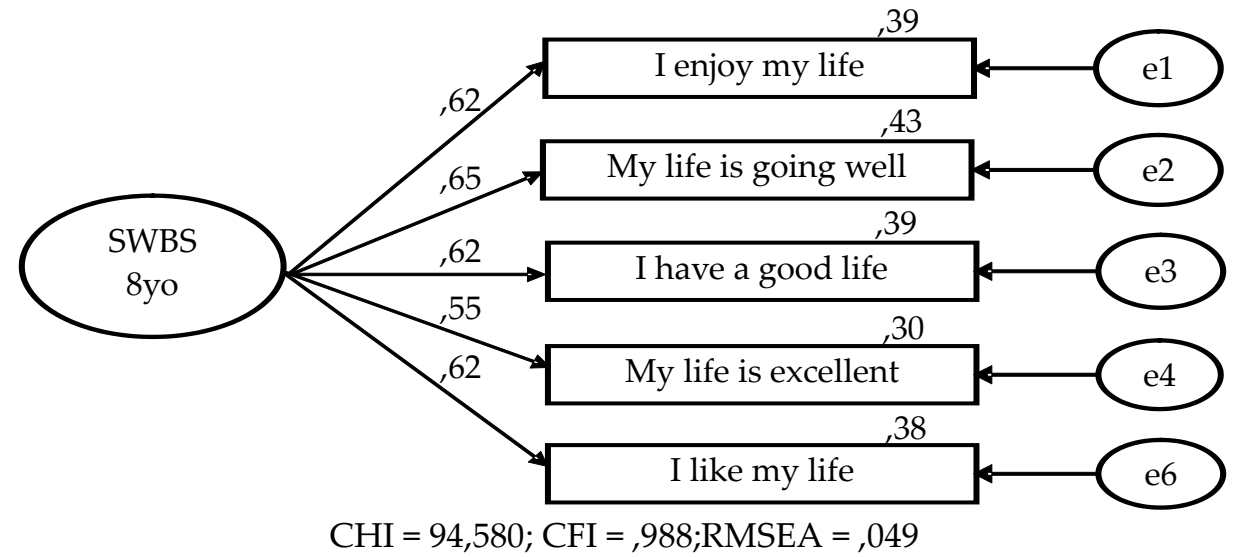

Figure 3. CFA of the context-free multi-item CW-SWBS for 8 year-olds 


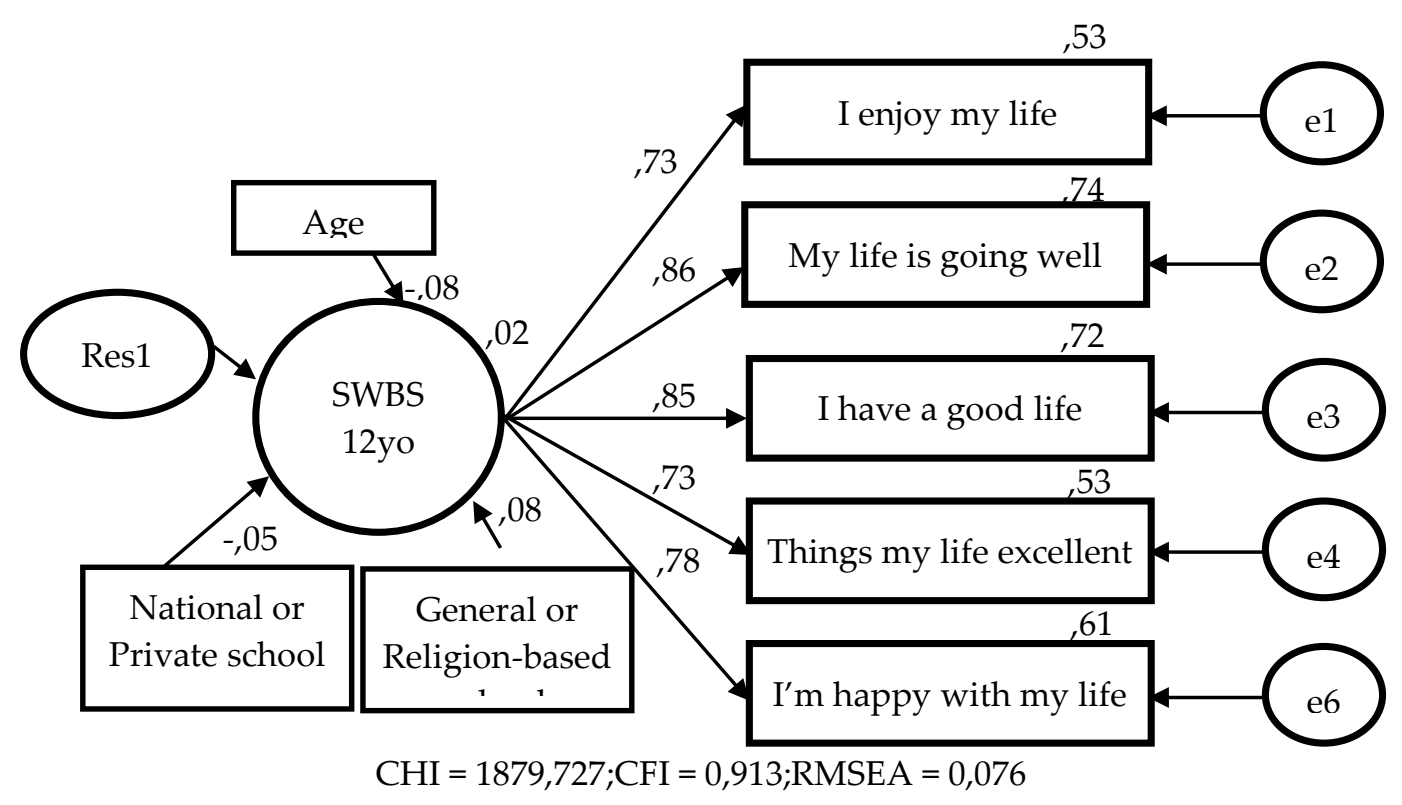

Figure 4. SEM for the 12-Year-Old Boys

\section{Discussion}

This study aimed to validate a new contextfree multi-item scale. Consistently with that aim, the original English version of the CWSWBS has been adapted into Indonesian. The back translation of the items showed that there were no essential differences between the two versions of the CW-SWBS. We tested The Indonesian version of CWSWBS to 22,616 children of three age groups $(8,10$, and 12) in 27 districts in West Java.

Data were representative for children in West Java Indonesia and were stratified by private and public schools, as well as religious and non-religious schools. The final sample showed equal numbers and the percentage of boys and girls in each age group. Descriptive statistics displayed data of children from an 8-year-olds group are reporting lower mean scores slightly on the 6 items of CW-SWBS compared to 10-yearold and 12-year-old groups.

Table 3 showed that children from three age groups have high mean scores (above 8.0) on answering 6 items of CWSWBS. Based on this data, we can say that children are happy and satisfied with their lives. BPS Indonesia had collected data on the level of happiness in Indonesian adults. The BPS Indonesia results showed that the score of happiness of Indonesian adults is 70.69 (BPS, 2017). Although the instruments were not identical, on $0-100$ scales, the mean scores among Indonesian children were much higher than the mean scores among Indonesian adults. 
THE CHILDREN'S WORLDS SUBJECTIVE WELL-BEING SCALE (CW-SWBS)

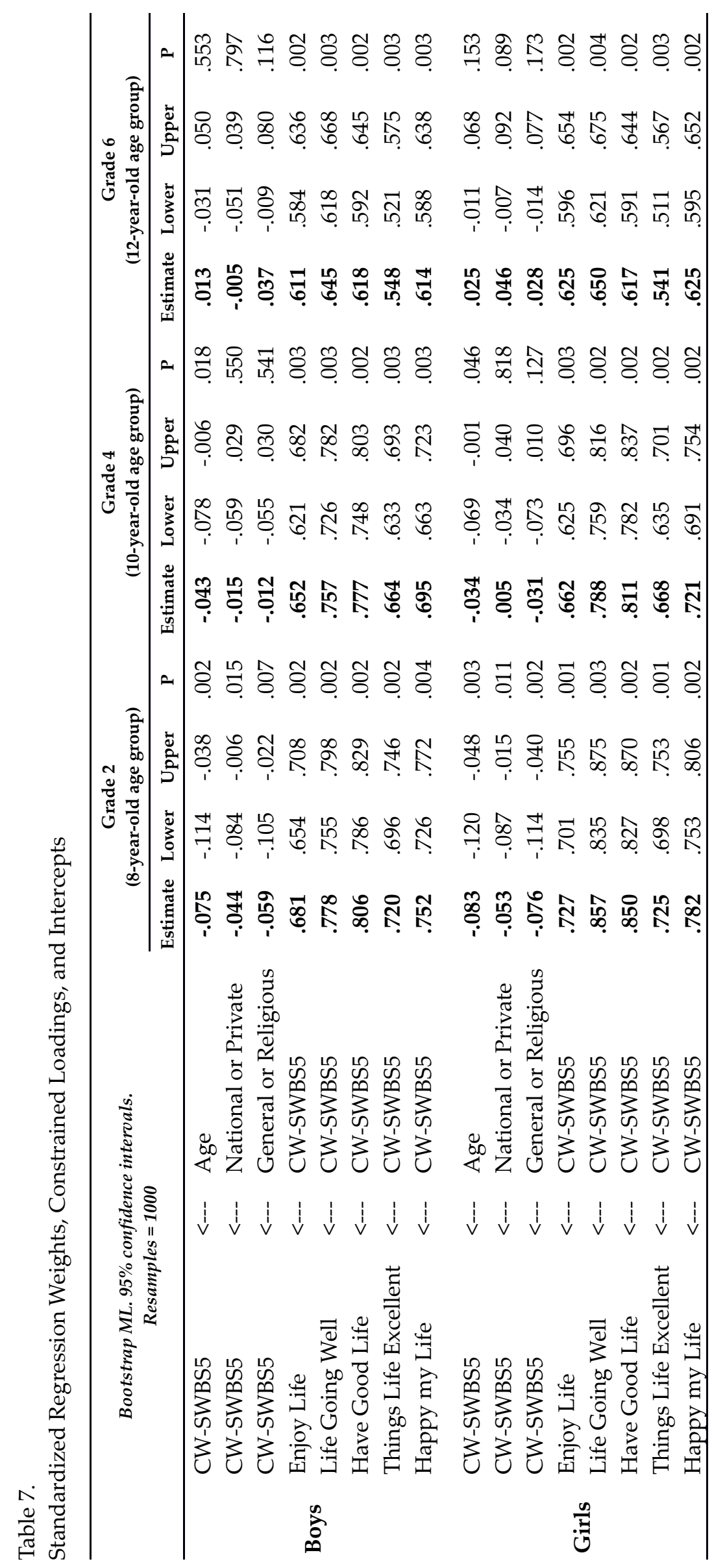


Confirmatory factor analysis of CWSWBS for the three age groups showed an excellent fit structure when only five of the original items were included in the model (the item "I like my life" removed). Therefore, the CW-SWBS can be used for Indonesian children using 5 items.

Using multi-group CFA (MCFA) models, metric and scalar factor invariance was tested by constraining the factor loadings and intercepts, and they were found to be tenable, suggesting there was no different answering style between the different groups of individuals in these three age groups. Correlation, regressions, and means could compare the groups of gender and types of school.

The effects of each item on the latent variable CW-SWBS were higher among girls than among boys (Table 7). SWB differences between genders had been reported in the case of adolescents with regards to specific life domains rather than general subjective well-being (Gonzálezcarrasco, et al., 2016). For instance, girls often displayed higher school satisfaction than boys (Liu, Mei, Tian, \& Huebner, 2015). Another example, 12 to 16-year-old girls showed higher scores in learningrelated satisfaction than boys of the same ages, while boys satisfaction score was higher in physical activities (Casas, Figuer, Gonzales, Malo, Alsinet, \& Subarroca, 2007).

These results were different from the happiness score of Indonesian adults. Indonesian index for happiness showed that Indonesian female adults had lower scores of happiness (70.30) compared to Indonesian male adults (71.12) (Statistik, 2017).

Age displayed very low and marginally significant adverse effects both for boys and girls for Grade 2 and Grade 4 age groups (8 and 10), and deficient and non-significant positive results for Grade 6. These findings suggested that withingroup SWB, scores decrease with age for Grade 2 and Grade 4, but not in Grade 6. Although many other research studies have reported a decreasing-with-age trend from 10 years of age on (see Casas \& GonzálezCarrasco, 2018, for a review), it typically said between age-groups, not within gradegroups, and it observed at 8 years of age in a very few countries (Casas \& GonzálezCarrasco, 2018). Perhaps this finding showed a specific phenomenon in Indonesia to explore further. Future research should also compare between agegroups trends for Indonesian children.

The types of school (public or private, and general or religious) displayed no significant effects on SWB for Grades 4 and 6 , and only minimal marginal significant effects for Grade 2 . These effects were very similar both for boys and girls. These results suggested that both boys and girls in Grade 2 reported slightly higher SWB when they attended public school than when they participated in private schools and when they participated in conventional schools than when they participate in religious schools. This interesting finding in Indonesia needs to be explored further because no previous studies were comparing the types of schools in Indonesia.

\section{Conclusion}

The new context-free multi-item scale CWSWBS (Children's Worlds Subjective WellBeing Scale) has been adapted into Indonesian. The validation test showed an excellent fit. The scale can be used in Indonesia using 5 items. This study has contributed to the area of research on children's subjective well-being in Indonesia since the survey of children's 
SWB in Indonesia is rare. This study is expected to encourage researchers to measure Indonesian children's SWB and increase the interest in researching children's SWB in Indonesia. Hopefully, this study will not only encourage researchers in the same area of benefits, but also raise the awareness among parents, government, policymakers, and stakeholders to monitor children's subjective well-being, and furthermore on helping children improving their wellbeing.

\section{Recommendations}

Despite the strengths in sampling and methodology, there were some limitations to this study. The sample was limited to only three age groups, which may not be representative for children below 8-yearolds or above 12-year-olds. The sample was also limited to only children who went to school. In Indonesia, some children do not go to school; therefore, this study might not be representative of children who do not go to school. To deepen our understanding of the measurement model of the CW-SWBS, researchers should further investigate $\mathrm{CW}$ SWBS using samples that represent different age groups of children and on children who do not go to school.

\section{Acknowledgment}

Data collection was supported by UNISBA (Universitas Islam Bandung), UNICEF Indonesia, and Statistics Indonesia (BPS). UNICEF Indonesia funded this survey and supported by BAPPENAS (Indonesian Ministry of National Development Planning). Thank you to all enumerators who had helped on data collection and to all participating schools and children.

\section{References}

Arbuckle, J. L. (2010). IBM SPSS® Amos $^{\mathrm{TM}}$ 19 user's guide. Crawfordville (Fl). Amos Development Corporation.

Borualogo, I. S., Gumilang, E., Mubarak, A., Khasanah, A. N., Wardati, M. A., Diantina, F. P., Permataputri, I., \& Casas, F. (2018). Process of translation of the Children's Worlds Subjective Well-Being Scale in Indonesia. Social and Humaniora Research Symposium, 307, 180-183. Retrieved from https://www.atlantis-press.com/ proceedings/sores-18/55915312

Byrne, B. M. (2010). Structural Equation Modeling with AMOS. Basic concepts, applications, and programming $2^{\text {nd }} e d$. New York: Routledge.

Casas, F. (2016a). Analyzing the comparability of 3 multi-item subjective wellbeing psychometric scales among 15 countries using samples of 10 and 12year-olds. Child Indicators Research, 6(2), 297-330. doi: 10.1007/s12187-015-9360$\underline{0 .}$

Casas, F. (2016b). Children, adolescents, and quality of life: The social sciences perspective over two decades. In Filomena Maggino (Eds.), A life devoted to quality of life. Festschrift in honor of Alex C. Michalos. (pp. 3-21). Dordrecht: Springer Publisher, 3-21. doi: 10.1007/978-3-319-20568-7

Casas, F., Bello, A., Gonzalez, M., \& Aligué, M. (2012). Personal well-being among Spanish adolescents. Journal of Social Research and Policy, 3(2), 19-45.

Casas, F., Figuer, C., Gonzales, M., Malo, S., Alsinet, C., \& Subarroca, S. (2007). The well-being of 12- to 16-year-old adolescents and their parents: Results from 1999 to 2003 Spanish samples. Social Indicator Research, 83(1), 87-115. 
Casas, F., \& González-Carrasco, M. (2018). Subjective well-being decreasing with age: New research on children over 8 . Child Development, 90(2), 375-394. doi: $\underline{10.1111 / \mathrm{cdev} .13133}$

Casas, F., González, M., Navarro, D., \& Aligue, M. (2013). Children as advisers of their researchers: Assuming a different status for children. Child Indicators Research, 6(2), 193-212. doi: $\underline{10.1007 / \mathrm{s} 12187-012-9168-0}$

Chen, F. F. (2007). The sensitivity of goodness of fit indexes to lack of measurement invariance. Structural Equation Modeling, 14(3), 464-504. doi: $\underline{10.1080 / 10705510701301834}$

Coenders, G., Batista-Foguet, J. M., \& Saris, W. (2005). Temas avanzados en modelos de ecuaciones estructurales (Advanced issues on structural equation modeling). Madrid: La Muralla.

Diener, E. (1984). Subjective well-being. Psychological Bulletin, 95(3), 542-575. doi: $10.1037 / 0033-2909.95 .3 .542$

Diener, E., Emmons, R. A., \& Griffin, S. (1985). The satisfaction with life scale. Journal of Personality Assessment, 49(1), 71-75. doi: 10.1207/s15327752 jpa4901 13

Diener, E., \& Lucas, R. E. (2015). National accounts of subjective well-being. American Psychologist, 70(3), 234-242. doi: 10.1037/a0038899

González-Carrasco, M., Casas, F., Vinas, F., Malo, S., Gras, M. E., \& Bedin, L. (2016). What leads subjective well-being to change throughout adolescence? An exploration of potential factors. Child Indicator Research, 10(1), 33-56. doi:

\section{$\underline{10.1007 / \mathrm{s} 12187-015-9359-6}$}

Huebner, E. (1991). Initial development of the student's life satisfaction scale. School Psychology International, 12, 231240. doi: $10.1177 / 0143034391123010$

Land, K. C., Lamb, V. L., \& Mustilo, K. S. (2001). Child and youth well-being in the United States, 1975-1998: Some findings from a new index. Social Indicators Research, 56(3), 241-320.

Liu, W., Mei, J., Tian, L., \& Huebner, E. S. (2015). Age and gender differences in the relation betweenschool-related social support and subjective wellbeingin school among students, Social Indicator Research, 125(3), 1065-1083. doi: $10.1007 / \mathrm{s} 11205-015-0873-1$

Rees, G., Andresen, S., \& Bradshaw, J. (2016). Children's views on their lives and well-being in 16 countries: A report on the Children's Worlds survey of children aged eight years old, 2013-15. Research Report. Jacobs Foundation. Retrieved from http://eprints.whiterose.ac.uk/ $\underline{95207 /}$

Savahl, S., Casas, F., \& Adams, S. (2017). Children's subjective well-being: Multi-group analysis among a sample of children from two socio-economic status groups in the Western cape, South Africa. Child Indicators Research, 10(2) 473-488. doi: 10.1007/s12187-0169392-0

Badan Pusat Statistik (2017). Indeks kebahagiaan Indonesia tahun 2017. https://www.bps.go.id/pressrelease/20 17/08/15/1312/indeks-kebahagiaanindonesia-tahun-2017-sebesar-70-69pada-skala-0-100.html 